\title{
Fibronectin glomerulopathy complicated with persistent cloaca and congenital esophageal atresia: a case report and literature review
}

\author{
Misaki Takii ${ }^{1}$,Takaichi Suehiro ${ }^{1,2^{*}} \mathbb{D}$, Aya Shima ${ }^{1}$, Hideki Yotsueda', Satoshi Hisano ${ }^{3}$ and Ritsuko Katafuchi ${ }^{4}$
}

\begin{abstract}
Background: Fibronectin glomerulopathy is a rare, inherited, autosomal dominant, glomerular disease characterized by proteinuria, microscopic hematuria, hypertension, massive glomerular deposits of fibronectin, and slow progression to end-stage renal failure. Because the incident of fibronectin glomerulopathy is extremely low, the pathophysiology, genetic abnormalities, epidemiology, and mechanisms remain to be elucidated.

Case presentation: We report a 21-year-old woman with fibronectin glomerulopathy, who had been diagnosed with persistent cloaca and congenital esophageal atresia at birth. She developed proteinuria and hematuria 7 months before admission. Urinary protein and serum creatinine levels were $3.38 \mathrm{~g} / \mathrm{gCr}$ and $0.73 \mathrm{mg} / \mathrm{dL}$. Renal biopsy showed severe mesangial widening due to massive deposits, which was positive periodic acid-Schiff and negative methenamine silver. Immunostaining was negative for immunoglobulin but positive for fibronectin. Electron microscopy showed diffuse mesangial granular deposits. Thus she was diagnosed with fibronectin glomerulopathy, despite a negative family history of kidney disease and lack of any known missense mutations of fibronectin 1 gene.

Conclusion: We report a patient who developed fibronectin glomerulopathy during the clinical course of extremely rare congenital malformations, including persistent cloaca and congenital esophageal atresia. We describe a case of this condition in detail and summarize the 75 case reports of fibronectin glomerulopathy.
\end{abstract}

Keywords: Fibronectin glomerulopathy, Fibronectin 1 gene, Congenital esophageal atresia, Persistent cloaca

\section{Background}

Fibronectin glomerulopathy is a rare, inherited, autosomal dominant, glomerular disease characterized by proteinuria, microscopic hematuria, hypertension, massive glomerular deposits of fibronectin, and slow progression to end-stage renal failure (ESRF) [1]. Three heterozygous missense mutations in the fibronectin 1 gene (FN1) associated with fibronectin glomerulopathy were first reported by Castelletti et al. in 2008 [2]. However, the pathophysiology, genetic abnormalities, epidemiology, and mechanisms of fibronectin glomerulopathy remain to be elucidated. Persistent cloaca and congenital esophageal atresia are extremely rare

\footnotetext{
* Correspondence: tsuehiro@nakabaru-hp.jp

'Department of Nephrology, Harasanshin Hospital, Fukuoka, Japan

2Department of Internal Medicine, Social Insurance Nakabaru Hospital, 2-12-1

Befukita, Shimemachi, Kasuya-gun, Fukuoka 811-2233, Japan

Full list of author information is available at the end of the article
}

congenital malformations, sometimes associated with the development of renal insufficiency [3, 4]. Here, we report a case of fibronectin glomerulopathy coexisting with congenital malformations, including persistent cloaca and congenital esophageal atresia.

\section{Case presentation}

A 21-year-old Japanese woman was admitted to our hospital because of proteinuria and hematuria. She had been diagnosed at birth with persistent cloaca and congenital esophageal atresia, and underwent enterostomy, cystostomy, and radical esophageal surgery, followed by repair of persistent cloaca and colostomy closure 2 years later. She was followed-up at the pediatric surgery and urology department, and developed with no major problems. Proteinuria and hematuria were detected at routine examination 
7 months prior to admission for the first time. No urological problems were detected at a visit to the urology department 3 months before admission. She had mild edema before admission; however its onset had been gradual and it was therefore not clear when the edema had started.

On admission, the patient's height was $158.6 \mathrm{~cm}$, her weight was $53.0 \mathrm{~kg}$, and her blood pressure was 101/ $80 \mathrm{mmHg}$. Physical examination revealed an abdominal midline operation scar and pretibial pitting edema. Urinary examination revealed a protein level of 3+ and 5-9 red blood cells per high-power field. Her urine protein/ creatinine ratio was $3.38 \mathrm{~g} / \mathrm{gCr}$, blood urea nitrogen was $13.2 \mathrm{mg} / \mathrm{dL}$, serum creatinine was $0.73 \mathrm{mg} / \mathrm{dL}$, and serum albumin was $3.6 \mathrm{~g} / \mathrm{dL}$. Serum C3 was $25 \mathrm{mg} / \mathrm{dL}$, C4 was $18.5 \mathrm{mg} / \mathrm{dL}$, and $50 \%$ hemolytic unit of complement ( $\mathrm{CH} 50)$ was $13 \mathrm{U} / \mathrm{mL}$. Chromosome G banding revealed a normal karyotype 46XX. Kidney ultrasound showed no kidney deformity. Kidneys size was normal.

A renal biopsy contained 24 glomeruli, all of which showed moderate to severe mesangial hypercellularity and increased homogenous materials in the mesangium. Which were positive with periodic acid-Schiff and were negative with methenamine silver (Fig. 1a, b). One glomerulus revealed fibrous crescent formation, and 11 showed segmental double contour of glomerular basement membrane. Immunofluorescence microscopy showed slight staining for fibrinogen, but no staining for IgG, IgA, IgM, kappa light chain and lambda light chain (Fig. 2). Electron microscopy showed massive granular deposits in the mesangial area and some subepithelial area (Fig. 1c, d). According to these findings, we speculated fibronectin glomerulopathy as a diagnosis. Thus, we performed immunoassays using anti-human fibronectin antibodies. The staining with IST-4, which detects plasma and cellassociated fibronectin, was positive but no staining was observed with IST-9, which stains only cell-associated fibronectin (Fig. 3). The mesangial deposits were therefore shown to comprise plasma fibronectin. The patient was finally diagnosed as fibronectin glomerulopathy.

Her family history was investigated further. Although her mother and younger sister had previously been detected to have proteinuria, their urine and blood tests were normal. Her father showed no urinary abnormalities and normal kidney function at his annual health examination. Given that no family history of renal disease could be identified, the current case was determined to be sporadic. The patient and her mother underwent genetic testing of the $F N 1$ gene, which revealed no abnormalities.

Treatment with an angiotensin II receptor antagonist and a sodium-restricted diet were started. However, 10 months after the kidney biopsy, the patient's proteinuria had increased and her renal function was deteriorated, with a urine protein/creatinine ratio of $9.52 \mathrm{~g} / \mathrm{gCr}$, serum creatinine $0.86 \mathrm{mg} / \mathrm{dL}$. Her serum albumin decreased to $2.0 \mathrm{~g} / \mathrm{dL}$.

\section{Discussion}

We herein present a patient who developed fibronectin glomerulopathy during the clinical course of rare congenital

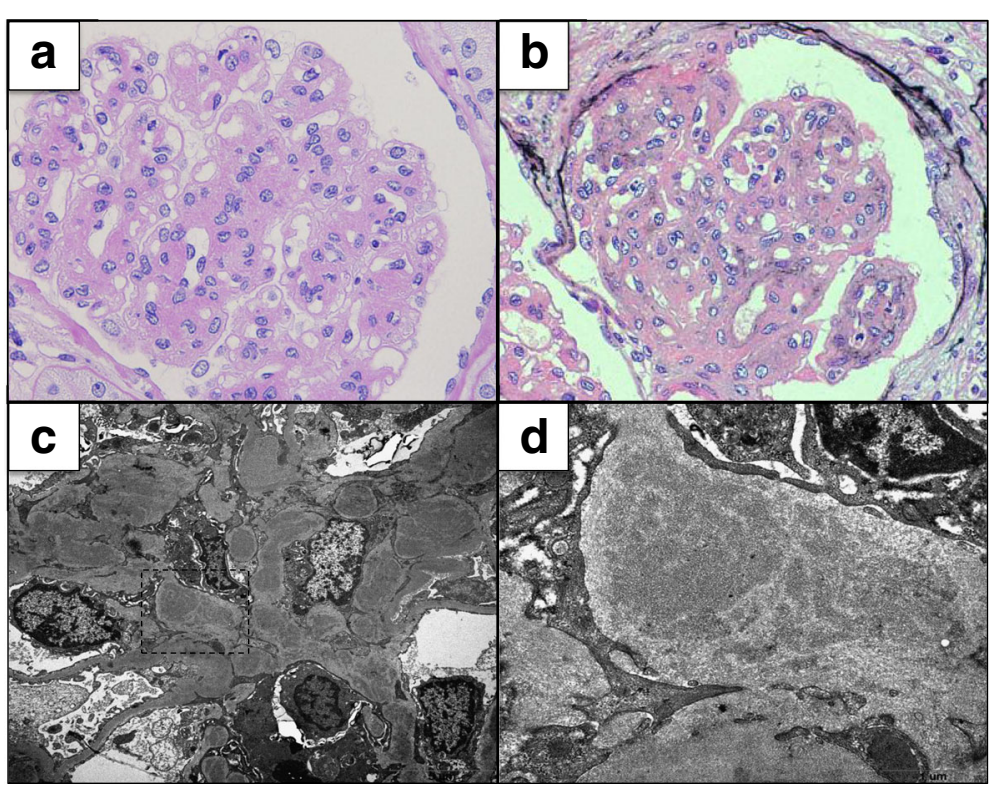

Fig. 1 Light and electron microscopic images of kidney biopsy sections. a Periodic acid-Schiff (PAS) stain. A glomerulus showing mesangial hypercellularity and increased in PAS-positive materials in the mesangium. Original magnification, $\times 400$. b Periodic acid-methenamine-silver stain. Increased materials in the mesangium were negative for methenamine-silver staining. Original magnification, $\times 200$. c, $\mathbf{d}$ Electron microscopy showed diffuse granular deposits in the mesangium and the subepithelial spaces of the glomerular basement membrane. Original magnification, $\times 4000$ (c) and $\times 10,000(\mathbf{d})$ 

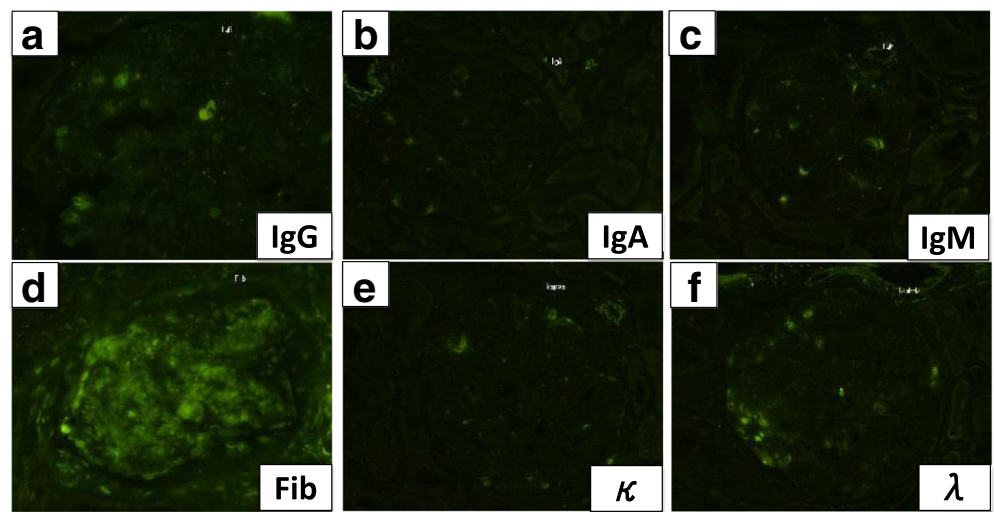

Fig. 2 Immunofluorescent staining. Immunofluorescent staining revealed slight staining for fibrinogen (d), but no staining for $\operatorname{lgG}$, IgA, IgM, kappa light chain and lambda light chain (a-c, e, f)

malformations, including persistent cloaca and congenital esophageal atresia. Notably, this case was sporadic, and showed no detectable FN1 mutations.

Fibronectin glomerulopathy is a rare, inherited, autosomal dominant, glomerular disease characterized by massive fibronectin deposits in the glomeruli. It was first recognized as a distinct clinical entity by Strøm et al. in 1995 [1]. Common clinical features are mild to nephrotic range proteinuria, microscopic hematuria, hypertension, and deterioration of renal function $[1,5]$. The disease often progresses to ESRF within 15-20 years from clinical onset $[5,6]$. Fibronectin glomerulopathy is usually diagnosed between the second and fifth decades of life [6], but the disease can manifest at any age, with the youngest patient diagnosed at 3 years old [7] and the oldest at 78 years old [5]. Diagnosis can only be made by renal biopsy, because the clinical features are nonspecific $[1,5]$. Generally, light microscopy shows enlarged glomeruli with minimal hypercellularity, with extensive deposits in the mesangium and subendothelial spaces. Electron microscopy shows finely granular or fibrillary mesangial and subendothelial electron-dense deposits [1], with granular deposits revealing a fibrillary substructure at higher magnifications, with randomly arranged fibrils $12-14 \mathrm{~nm}$ wide [5]. The deposits in fibronectin glomerulopathy are non-immunoreactive by routine immunofluorescence microscopy, and an accurate diagnosis is accomplished by immunofluorescent staining for fibronectin [6]. In immunolocalization studies, fibrillary deposits were shown to be positive with IST-4, which is an antibody that detects both plasma fibronectin and cell-associated fibronectin, but were only weakly stained with IST-9, which is specific for cellassociated fibronectin, suggesting that the fibrils were deposits of plasma fibronectin [8].

The current case was notable for the presence of rare congenital malformations. Persistent cloaca is an extremely rare congenital malformation, occurring in only one in 50,000 live births. It is characterized by a single perineal opening for the urinary, gastrointestinal, and reproductive tracts [9]. Eighty percent of patients with persistent cloaca are also born with a structural abnormality

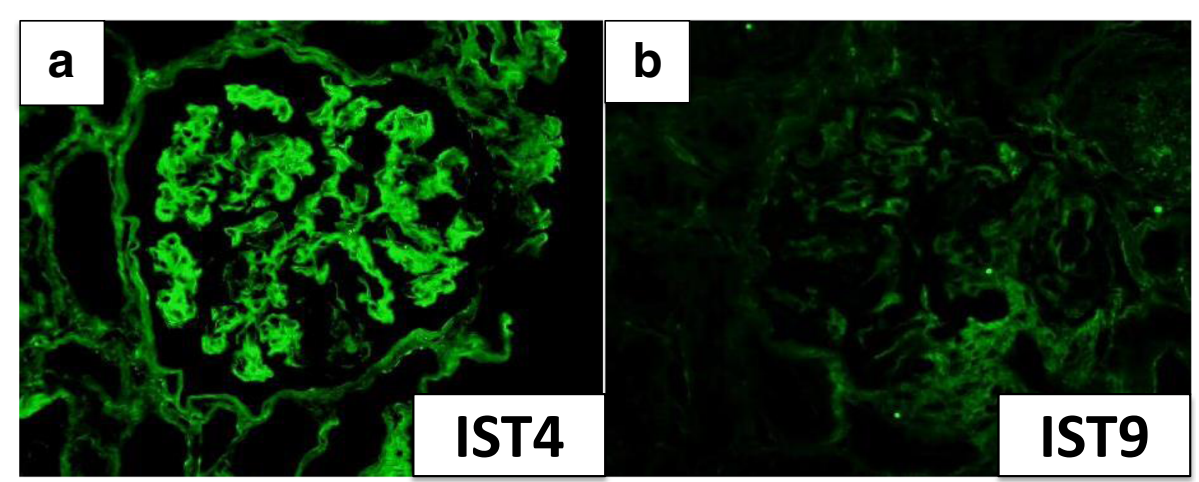

Fig. 3 Immunohistochemical staining for fibronectin. a Staining with IST-4 showed a positive mesangial pattern. b Staining with IST-9 was negative 
Table 1 Clinical characteristics of the 75 reported cases of fibronectin glomerulopathy

\begin{tabular}{|c|c|c|c|c|c|c|c|c|}
\hline & & Age & Sex & UP & Cre & Comorbidity & Family history & FN1 mutation \\
\hline 1 & Strøm et al. & 59 & $F$ & 3.9 & 1.0 & NA & + & NA \\
\hline 2 & & 18 & M & 4.5 & 1.2 & NA & + & NA \\
\hline 3 & & 24 & M & 14.0 & 1.0 & NA & + & NA \\
\hline 4 & & 21 & M & $2-4$ & 1.0 & NA & + & NA \\
\hline 5 & & 19 & M & NA & NA & NA & + & NA \\
\hline 6 & & 22 & $\mathrm{~F}$ & NA & NA & NA & + & NA \\
\hline 7 & & 25 & $\mathrm{~F}$ & 5.0 & NA & NA & + & NA \\
\hline 8 & & 14 & $\mathrm{~F}$ & NS & 0.6 & NA & + & NA \\
\hline 9 & & 64 & M & 2.0 & 1.1 & NA & + & NA \\
\hline 10 & & 16 & M & 5.0 & NA & NA & + & NA \\
\hline 11 & & 23 & M & 0.6 & 0.8 & NA & + & NA \\
\hline 12 & & 25 & $\mathrm{~F}$ & 0.3 & 0.8 & NA & + & NA \\
\hline 13 & & 30 & M & 2.1 & 1.3 & NA & + & NA \\
\hline 14 & & 24 & M & 1.3 & 1.4 & NA & + & NA \\
\hline 15 & & 26 & $\mathrm{~F}$ & + & NA & cerebrovascular hemorrhage & + & NA \\
\hline 16 & & 29 & M & $3+$ & 1.8 & cerebrovascular hemorrhage & + & NA \\
\hline 17 & & 15 & M & $4+$ & NA & $\begin{array}{l}\text { cerebrovascular hemorrhage } \\
\text { myocardial infarction }\end{array}$ & + & NA \\
\hline 18 & & 14 & M & $3+$ & 0.8 & NA & + & NA \\
\hline 19 & & 44 & M & 4.7 & 1.6 & NA & + & NA \\
\hline 20 & & 37 & $\mathrm{~F}$ & 0.7 & 0.9 & NA & + & NA \\
\hline 21 & & 33 & M & 1.0 & 1.0 & NA & + & NA \\
\hline 22 & & 31 & M & 2.1 & 1.0 & NA & + & NA \\
\hline 23 & & 53 & M & NS & NA & renal cell carcinoma & + & NA \\
\hline 24 & Gemperle et al. & 35 & $\mathrm{~F}$ & 5.6 & NA & NA & + & NA \\
\hline 25 & & 31 & M & 1.8 & NA & myocardial infarction & + & NA \\
\hline 26 & & 38 & M & + & NA & NA & + & NA \\
\hline 27 & & 46 & $\mathrm{~F}$ & 0.1 & NA & NA & + & NA \\
\hline 28 & & 42 & M & + & NA & renal cell carcinoma & + & NA \\
\hline 29 & & 30 & M & 0.5 & NA & myocardial infarction & + & NA \\
\hline 30 & & 33 & $\mathrm{~F}$ & 0.7 & NA & NA & + & NA \\
\hline 31 & & 32 & M & 1.0 & NA & myocardial infarction & + & NA \\
\hline 32 & & 20 & M & + & NA & NA & + & NA \\
\hline 33 & Sato et al. & 23 & M & 2.0 & 0.9 & NA & + & NA \\
\hline 34 & Uesugi et al. & 4 & M & 8.0 & 0.2 & NA & + & NA \\
\hline 35 & & 19 & $\mathrm{~F}$ & 7.0 & 0.6 & NA & NA & NA \\
\hline 36 & & 27 & M & 1.0 & 0.8 & NA & + & NA \\
\hline 37 & & 58 & M & 12.0 & 1.6 & NA & + & NA \\
\hline 38 & & 75 & M & 2.1 & NA & NA & + & NA \\
\hline 39 & Niimi et al. & 3 & M & 8.0 & 0.2 & NA & + & NA \\
\hline 40 & Castelletti et al. & 59 & $\mathrm{~F}$ & NS & Nomal & NA & + & + \\
\hline 41 & & 44 & M & 0.3 & 1.4 & NA & + & + \\
\hline 42 & & 40 & M & NA & 2.2 & NA & + & + \\
\hline 43 & & 35 & M & NS & 1.5 & NA & + & + \\
\hline
\end{tabular}


Table 1 Clinical characteristics of the 75 reported cases of fibronectin glomerulopathy (Continued)

\begin{tabular}{|c|c|c|c|c|c|c|c|c|}
\hline 44 & & 18 & $M$ & 4.2 & 1.4 & NA & + & + \\
\hline 45 & & 27 & M & 0.7 & 0.8 & NA & + & + \\
\hline 46 & & 16 & M & NA & Nomal & NA & + & + \\
\hline 47 & & 12 & M & 7.5 & 0.7 & NA & + & + \\
\hline 48 & Yong et al. & 41 & M & NS & 1.7 & NA & + & NA \\
\hline 49 & Nadamuni et al. & 50 & $\mathrm{~F}$ & 4.8 & 0.8 & anxiety, depression & + & + \\
\hline 50 & Otsuka et al. & 52 & $\mathrm{~F}$ & 0.4 & 1.5 & $\begin{array}{l}\text { atrial septal defect } \\
\text { tricuspid regurgitation }\end{array}$ & - & NA \\
\hline 51 & Yoshino et al. & 67 & M & 3.6 & 1.7 & $\begin{array}{l}\text { thymic carcinoid } \\
\text { gastric cancer }\end{array}$ & - & NA \\
\hline 52 & Baydar et al. & 24 & M & 1.0 & 0.8 & asthma & + & + \\
\hline 53 & Ishimoto et al. & 78 & $\mathrm{~F}$ & 10.2 & 1.1 & NA & - & - \\
\hline 54 & Chen et al. & 34 & $\mathrm{~F}$ & 3.6 & 0.7 & NA & - & NA \\
\hline 55 & & 24 & M & 3.9 & 2.0 & NA & - & NA \\
\hline 56 & & 46 & M & 3.7 & 0.8 & NA & + & NA \\
\hline 57 & & 32 & M & 1.2 & 0.9 & NA & - & NA \\
\hline 58 & & 27 & $\mathrm{~F}$ & 3.8 & 0.5 & NA & - & NA \\
\hline 59 & & 26 & M & 7.4 & 1.5 & NA & - & NA \\
\hline 60 & & 19 & M & 9.1 & 1.4 & NA & - & NA \\
\hline 61 & & 32 & $\mathrm{~F}$ & 9.1 & 3.4 & NA & - & NA \\
\hline 62 & & 29 & M & 7.0 & 1.5 & NA & - & NA \\
\hline 63 & & 19 & $\mathrm{~F}$ & 2.8 & 0.6 & NA & - & NA \\
\hline 64 & Ohtsubo et al. & 20 & M & 0.86 & $92.1^{\mathrm{a}}$ & NA & + & + \\
\hline 65 & & 13 & $F$ & 1.6 & $115^{\mathrm{a}}$ & NA & - & + \\
\hline 66 & & 35 & $F$ & ESRD & ESRD & NA & + & + \\
\hline 67 & & 54 & $\mathrm{~F}$ & ESRD & ESRD & NA & + & + \\
\hline 68 & & 35 & $\mathrm{~F}$ & 5.85 & $76.3^{\mathrm{a}}$ & NA & - & + \\
\hline 69 & & 15 & $\mathrm{~F}$ & 0.51 & $86.5^{\mathrm{a}}$ & NA & + & + \\
\hline 70 & & 53 & $\mathrm{~F}$ & 11.8 & $48^{\mathrm{a}}$ & NA & - & + \\
\hline 71 & & 16 & M & 0.44 & $124.1^{\mathrm{a}}$ & NA & - & + \\
\hline 72 & & 74 & M & 3.56 & $63^{a}$ & NA & - & + \\
\hline 73 & & 38 & $\mathrm{~F}$ & 4.9 & $55.3^{\mathrm{a}}$ & NA & + & + \\
\hline 74 & & 14 & $\mathrm{~F}$ & 10.1 & $123.4^{\mathrm{a}}$ & NA & - & + \\
\hline 75 & & 64 & M & 4.6 & $46.3^{\mathrm{a}}$ & NA & - & + \\
\hline 76 & This case & 21 & $\mathrm{~F}$ & 3.4 & 0.7 & $\begin{array}{l}\text { persistent cloaca } \\
\text { congenital esophageal atresia }\end{array}$ & - & - \\
\hline
\end{tabular}

$F$ female, $M$ male, UP urinary protein $(\mathrm{g} / 24 \mathrm{~h})$, Cre creatinine $(\mathrm{mg} / \mathrm{dl}), N A$ not available, $N S$ nephrotic syndrome, ESRD end-stage renal disease a eGFR $\left(\mathrm{ml} / \mathrm{min} / 1.73 \mathrm{~m}^{2}\right)$

of the urinary tract, including renal dysplasia, ectopic kidney, solitary kidney, duplex kidneys, and ureteropelvic junction obstruction [3]. Vesicoureteral reflux occurs in $41 \%-57 \%$ of persistent cloaca cases, and sacral abnormalities are diagnosed in $57 \%$. About half of all patients with persistent cloaca develop chronic renal failure, with a glomerular filtration rate of $<80 \mathrm{~mL} / \mathrm{min} / 1.73 \mathrm{~m}^{2}$, and $17 \%$ progress to ESRF [3, 10]. Congenital esophageal atresia is also a relatively rare congenital malformation, occurring in one in 4000 live births [11]. It is a developmental defect of the foregut, characterized lack of continuity of the esophagus [4]. There have been few reports of renal disease associated with congenital esophageal atresia. Patients displaying the VATER association, which includes vertebral defects, anal atresia, trachea-esophageal fistula with esophageal atresia, and radial and renal dysplasia, often develop chronic renal failure [12], and congenital nephrotic syndrome [13]. 
Renal abnormality with 17q12 duplication have also been reported in patients with esophageal atresia [14]. However, as far as we investigated there has been no case report of fibronectin glomerulopathy complicated with these congenital malformations.

Seventy-five cases of fibronectin glomerulopathy have been reported, so far with full clinical data (Table 1) [1, $2,5-8,15-22]$. Proteinuria was recorded in 69 cases, of which 35 had nephrotic-range proteinuria $(>3.5 \mathrm{~g} / 24 \mathrm{~h})$. Twenty-two cases had proteinuria and serum albumin, of which 15 met the definition of nephrotic syndrome (proteinuria $>3.5 \mathrm{~g} / 24 \mathrm{~h}$ and serum albumin $<3.0 \mathrm{~g} / \mathrm{dl}$ ).

Twelve of these 75 cases $(16 \%)$ had some comorbidities, including two with renal cell carcinoma, but no cases had congenital malformations. The current patient developed fibronectin glomerulopathy, during the clinical course of persistent cloaca and congenital esophageal atresia. The direct pathophysiological relationship between fibronectin glomerulopathy and these congenital malformations remains unclear.

There have been numerous reports of cases with detailed family histories, but few reports of sporadic cases, such as the present patient [5, 19, 20, 22]. Eighteen of the 75 reported cases (24\%) had no apparent family history of renal diseases. Furthermore, even in cases with a family history, the clinical courses were found to vary within families. For example, one patient progressed to ESRF, while another presented with no urine abnormalities $[1,15]$. Ohtsubo et al. reported that some patients with FN1 mutation were asymptomatic, and suggested that this genetic abnormality did not necessarily cause a phenotypic abnormality [8]. Furthermore, Castelletti et al. also reported a patient with fibronectin glomerulopathy and a genetic mutation, though the same mutation was not found in his family members, suggesting that it was a de novo mutation [2]. In the current case, there might have been asymptomatic patients with FN1 mutations in her family, or the mutation might have arisen de novo. We did not perform renal biopsies and genetic tests in all her family members, and were therefore unable to establish the precise etiology of her disease.

Mutations at the FN1 gene locus at 2q32 were first confirmed by Castelletti et al. in 2008 [2]. They identified three heterozygous missense mutations, Y973C, W1925R, and L1974R, but reported that these mutations only accounted for $40 \%$ of cases of fibronectin glomerulopathy [2]. Ohtsubo et al. subsequently identified six FN1 mutations in 12 families with fibronectin glomerulopathy, including five novel FN1 mutations (p.Pro969Leu, p.Pro1472del, p.Trp1925Cys, p.Lys1953_Ile1961del, and p.Leu1974Pro) [8]. However, none of these previously identified FN1 mutations were detected in the current patient, despite genetic testing. This finding was in line with a previous report suggesting that some patients with fibronectin glomerulopathy showed no causative gene mutations in $F N 1$ [2, 5].

\section{Conclusion}

We present a patient who developed fibronectin glomerulopathy, with no apparent familial history and no FN1 mutation, during the clinical course of rare congenital malformations, including persistent cloaca and congenital esophageal atresia.

\section{Abbreviations \\ CH50: $50 \%$ hemolytic unit of complement; ESRF: End-stage renal failure; FN1: Fibronectin 1 gene}

\section{Acknowledgements}

We thank Kandai Nozu (Department of Pediatrics, Kobe University Graduate School of Medicine) for conducting FN1 analysis.

\section{Funding}

Not applicable.

Availability of data and materials

All information supporting the conclusions of this case report has been included in the article.

\section{Authors' contributions}

MT was in charge of the patient's treatment and care in hospital and drafted the manuscript. TS supervised the management of patient and revised the final manuscript for submission. AS participated in the management of patient and helped in drafting the manuscript. HY was in charge of outpatient treatment and helped in drafting the manuscript. SH performed immunoassays using antihuman fibronectin antibodies and was involved in the diagnostic procedures. RK performed diagnosis of renal biopsy and critically revised the manuscript. All authors read and approved the final manuscript.

\section{Ethics approval and consent to participate}

Not applicable.

\section{Consent for publication}

Written informed consent was obtained from the patient for publication of this case report and any accompanying images.

\section{Competing interests}

The authors declare that they have no competing interests.

\section{Publisher's Note}

Springer Nature remains neutral with regard to jurisdictional claims in published maps and institutional affiliations.

\section{Author details}

'Department of Nephrology, Harasanshin Hospital, Fukuoka, Japan. ${ }^{2}$ Department of Internal Medicine, Social Insurance Nakabaru Hospital, 2-12-1 Befukita, Shimemachi, Kasuya-gun, Fukuoka 811-2233, Japan. ${ }^{3}$ Department of Pathology, Faculty of Medicine, Fukuoka University, Fukuoka, Japan. ${ }^{4}$ Kidney Unit, National Fukuoka-Higashi Medical Center, Fukuoka, Japan.

Received: 14 February 2017 Accepted: 22 August 2017

Published online: 06 September 2017

\section{References}

1. Strøm EH, Banfi G, Krapf R, Abt AB, Mazzucco G, Monga G, Gloor F, Neuweiler J, Riess R, Stosiek P, Hebert LA, Sedmak DD, Gudat F, Mihatsch MJ. Glomerulopathy associated with predominant fibronectin deposits: a newly recognized hereditary disease. Kidney Int. 1995;48:163-70.

2. Castelletti F, Donadelli R, Banterla F, Hildebrandt F, Zipfel PF, Bresin E, Otto E, Skerka C, Renieri A, Todeschini M, Caprioli J, Caruso RM, Artuso R, Remuzzi $\mathrm{G}$, Noris M. Mutations in FN1 cause glomerulopathy with fibronectin deposits. Proc Natl Acad Sci U S A. 2008;105:2538-43. 
3. Warne SA, Wilcox DT, Ledermann SE, Ransley PG. Renal outcome in patients with cloaca. J Urol. 2002;167:2548-51.

4. Brosens E, Ploeg M, van Bever Y, Koopmans AE, IJsselstijn H, Rottier RJ, Wijnen R, Tibboel D, de Klein A. Clinical and etiological heterogeneity in patients with tracheo-esophageal malformations and associated anomalies. Eur J Med Genet. 2014;57:440-52.

5. Ishimoto I, Sohara E, Ito E, Okado T, Rai T, Uchida S. Fibronectin glomerulopathy. Clin Kidney J. 2013;6:513-5.

6. Nadamuni M, Piras R, Mazbar S, Higgins JP, Kambham N. Fibronectin glomerulopathy: an unusual cause of adult-onset nephrotic syndrome. Am J Kidney Dis. 2012;60:839-42.

7. Niimi K, Tsuru N, Uesugi N, Takebayashi S. Fibronectin glomerulopathy with nephrotic syndrome in a 3-year-old male. Pediatr Nephrol. 2002;17:363-6.

8. Ohtsubo H, Okada T, Nozu K, Takaoka Y, Shono A, Asanuma K, Zhang L, Nakanishi K, Taniguchi-lkeda M, Kaito H, lijima K, Nakamura S. Identification of mutations in FN1 leading to glomerulopathy with fibronectin deposits. Pediatr Nephrol. 2016:31:1459-67.

9. Ishibashi M, Tanaka H, Ito M, Uketa E, Mori N, Hanaoka U, Kanenishi K, Hata T. Antenatal three-dimensional sonographic diagnosis of persistent cloaca. J Med Ultrason. 2013;40:275-7.

10. Caldwell BT, Wilcox DT. Long-term urological outcomes in cloacal anomalies. Semin Pediatr Surg. 2016;25:108-11.

11. Murase N, Uchida H, Kaneko K, Ono Y, Makita S, Yokota K. Prophylactic effect of $\mathrm{H} 2$ blocker for anastomotic stricture after esophageal atresia repair. Pediatr Int. 2015;57:461-4.

12. Henmi N, Okubo S, Kasahara T, Okugawa T, Yamazaki H, Harada W, Uchiyama M. A case of esophageal atresia with tracheoesophageal fistula, imperforate anus, persistent cloaca, incomplete fusion of the labium and chronic renal failure due to urethral obstruction. Pediatr Int. 2000;42:585-8.

13. Stefanidis CJ, Nakopoulou L, Kapetanakis J, Kourakis G, Dellagrammaticas I. Congenital nephrotic syndrome and tracheoesophageal fistula with esophageal atresia type IIIB. Prog Clin Biol Res. 1989;305:211-4.

14. Faguer S, Chassaing N, Bandin F, Prouheze C, Arveiler B, Rooryck C, Nogier MB, Chauveau D, Calvas P, Decramer S. A $17 q 12$ chromosomal duplication associated with renal disease and esophageal atresia. Eur J Med Genet. 2011;54:e437-40

15. Gemperle O, Neuweiler J, Reutter FW, Hildebrandt F, Krapf R. Familial glomerulopathy with giant fibrillar fibronectin-positive deposits: 15-year follow-up in a large kindred. Am J Kidney Dis. 1996;28:668-75.

16. Sato H, Matsubara M, Marumo R, Soma J, Kurosawa K, Taguma Y, Saito T. Familial lobular glomerulopathy: first case report in Asia. Am J Kidney Dis. 1998:31:E3-5.

17. Uesugi N, Katafuchi R, Taguchi H, Turu M, Sakata N, Takebayashi S. Clinicopathological and morphometrical analysis of 5 cases from 4 families of fibronectin glomerulopathy. Nihon Jinzo Gakkai Shi. 1999;41:49-59. in Japanese, Abstract in English

18. Yong JL, Killingsworth MC, Spicer ST, Wu XJ. Fibronectin non-amyloid glomerulopathy. Int J Clin Exp Pathol. 2010;3:210-6.

19. Otsuka Y, Takeda A, Horike K, Inaguma D, Goto N, Watarai Y, Uchida K, Mihatsch MJ, Joh K, Morozumi K. A recurrent fibronectin glomerulopathy in a renal transplant patient: a case report. Clin Transpl. 2012;26:58-63.

20. Yoshino M, Miura N, Ohnishi T, Suzuki K, Kitagawa W, Nishikawa K, Imai H. Clinicopathological analysis of glomerulopathy with fibronectin deposits GFND: a case of sporadic, elderlyonset GFND with codeposition of IgA, C1q, and fibrinogen. Intern Med. 2013;52:1715-20.

21. Ertoy Baydar D, Kutlugun AA, Bresin E, Piras R. A case of familial glomerulopathy with fibronectin deposits caused by the Y973C mutation in fibronectin. Am J Kidney Dis. 2013;61:514-8.

22. Chen $\mathrm{H}$, Bao H, Xu F, Zhu X, Zhu M, He Q, Zeng C, Liu Z. Clinical and morphological features of fibronectin glomerulopathy: a report of ten patients from a single institution. Clin Nephrol. 2015;83:93-9.

\section{Submit your next manuscript to BioMed Central and we will help you at every step:}

- We accept pre-submission inquiries

- Our selector tool helps you to find the most relevant journal

- We provide round the clock customer support

- Convenient online submission

- Thorough peer review

- Inclusion in PubMed and all major indexing services

- Maximum visibility for your research

Submit your manuscript at www.biomedcentral.com/submit
Biomed Central 